\title{
Evaluation of chemical composition of roots of three sugar beets varieties growing under different water deficit and harvesting dates in Upper Egypt
}

\author{
Omar M. Yassin ${ }^{a^{*}}$, Saleh M. Ismail ${ }^{b}$, M.A. Gameh ${ }^{b}$, F. A. F. Khalil ${ }^{a}$ and Ezzat M. Ahmed ${ }^{b}$
}

${ }^{a}$ Soils, Water, and Environment Research Institute, Agricultural Research Center, Giza, Egypt ${ }^{b}$ Soils and Water Department, Faculty of Agriculture, Assiut University, Assiut, Egypt

\begin{tabular}{l}
\hline C H R O N I C L E \\
\hline Article history: \\
Received June 27, 2021 \\
Received in revised form \\
July 19, 2021 \\
Accepted November 11, 2021 \\
Available online \\
November 11, 2021 \\
\hline Keywords: \\
Irrigation \\
Harvest age \\
Chemical composition \\
Juice quality sugar beet varieties \\
Upper Egypt
\end{tabular}

\section{A B S T R A C T}

Field experiments were carried out at Shandaweel Agricultural Research Station, Sohag, Egypt to study the effects of deficit irrigation and harvesting date chemical composition of three sugar beet varieties. A split block design with three replications was used. Main blokes were assigned to three irrigation water regimes $(100 \%, 85 \%$, and $70 \%$ of water requirement). The sub blot was occupied by three harvesting dates (180, 195 and 210 days). Sub- sub plots comprised three sugar beet varieties namely (RAVEL, SV1841and SA1686). Results indicated that reducing water supply reduced alpha - amino $\mathrm{N}$ present in the second season, Na present in the second season, and $\mathrm{K}$ present and sugar lost to molasses, but increased sucrose present, extractable present, QZ present, purity present, extractability present. Increasing harvesting date increased $\mathrm{K}$ present, sucrose present, extractable present, QZ present, purity present, extractability present but reduced alpha - amino $\mathrm{N}$ present, $\mathrm{Na}$ present and sugar lost to molasses in the second season. Sucrose present, extractable present, QZ present purity present and extractability present of RAVEL and SA1686 varieties were almost comparable but higher than those of SV1841 variety.

\section{Introduction}

The uses of functionalized organic and inorganic compounds has been extensively developed, which is presented in a lot of scientific papers. ${ }^{1-17}$ The optimum water use in agricultural production is considered as one of the most important environmental factors affecting plant growth and development, particularly in arid and semi-arid regions. ${ }^{18}$ Egypt is a country with limited water resources and large population growth rate. Therefore, the Egyptian Government imports about 1.10 million ton of sugar every year to face the rapid increase of population consumption. Sugar beet plays a prominent role in sugar production and accounts for the second largest production for sugar after sugarcane with about $37.3 \%$ of the local sugar production (1.61 million ton). Sugar beet is one of the highest water consuming crops due to its long growth period, with an annual consumption of 350 to $1150 \mathrm{~mm}$ in different regions of the world. Although, it is a drought resistant plant that could produce economic yield even with declined irrigation. ${ }^{19}$ The harvesting age is one of the main factors which directly affect maturity and consequently root yield and juice quality of sugar beet. Sugar beet varieties differ inherently in their maturity ages, which extend from 150 to 240 days, through which changes in quality, yield and its components occur until they reach their maximum values. ${ }^{20-22}$ Sugar beet variety is considered one of the essential wings of sugar production, in terms of its root yield and quality characteristics. In this context $\mathrm{t}^{23-25}$ they found differences among beet varieties.

The main objectives of this study were to evaluate chemical composition of roots of three sugar beets varieties growing under different water deficiencies and harvesting dates in Upper Egypt.

* Corresponding author.

E-mail address: omar66004510@gmail.com (O. M. Yassin)

C 2022 by the authors; licensee Growing Science, Canada doi: $10.5267 /$ j.ccl.2021.11.003 


\section{Results and Discussion}

\subsection{Technological characteristics of sugar beet juice}

During the processing of sugar beet, one of the most important raw substance technological parameter are nitrogen, sodium and potassium, which cannot be removed via purification of juice, may be lead to increment the thickness of juice and reduce the recovery rate of sugar as well as causing an increment in losses sugar rate.

\subsubsection{Effect of irrigation water regimes on Alpha-amino $N$ percentages, Na percentages and K percentages.}

The data in Table 1 showed the insignificant effect of water stress treatments on impurities percentages $(\alpha$ - amino nitrogen percentages, sodium percentages and Potassium percentages) in the two seasons. From results it could be seen that level of $70 \%$ WR recorded the best value of $\alpha$ - amino N\% in the first season but the best value of $\alpha$ - amino N\% in the second season was with $100 \% \mathrm{WR}$, while the highest value of sodium $\%$ was recorded $4.388 \%$ compared with irrigation $70 \%$ WR in the first season only and $3.713 \%$ and compared with irrigation $85 \% \mathrm{WR}$ in the second season only and the highest values of $\mathrm{K} \%$ was recorded $5.104 \%$ compared with irrigation $70 \mathrm{WR}$ in the first season only and $4.958 \%$ and compared with irrigation $100 \mathrm{WR}$ in the second season only. These data are in partial agreement with those obtained by this is probably due to the various counteracting effects of deficit irrigation on ion uptake. ${ }^{26-28}$

\subsubsection{Effect of harvesting dates Alpha - amino N percentages, Na percentages and K percentages.}

Data listed in Table 1 clear that the tested harvesting ages led to insignificant effects in the values of $\alpha$ - amino $\mathrm{N}$ and potassium content, meanwhile the difference between harvesting ages did reach the level of significance on sodium contents in the second seasons. The highest values of sodium \% was recorded 3.826\% from 195 days, the amount of harvest age from 210 days gave the lowest values in both seasons this superiority may be due to the decreased temperature at this time of harvest. ${ }^{29-32}$

\subsubsection{Effect of sugar beet varieties on Alpha - amino N percentages, Na percentages and K percentages.}

Results collected in the same Tables 1 showed that impurities percentages characteristics $(\alpha-$ amino $\mathrm{N} \%$, Na\% and $\mathrm{K}$ $\%)$ among tested sugar beet varieties, were insignificantly affected in both seasons. ${ }^{33,30,18}$

Table 1. Means of Alpha amino - N \%, Sodium \%and Potassium (K) \%of sugar beet crop as effected by irrigation water regimes, harvesting dates and varieties for two growing seasons of 2018/2019 and 2019/2020.

\begin{tabular}{|c|c|c|c|c|c|c|}
\hline \multirow{2}{*}{ Treatments } & \multicolumn{2}{|c|}{ Alpha amino $-\mathrm{N} \%$} & \multicolumn{2}{|c|}{ Sodium $\%(\mathrm{Na})$} & \multicolumn{2}{|c|}{ Potassium (K) \% } \\
\hline & $2018 / 2019$ & $2019 / 2020$ & $2018 / 2019$ & $2019 / 2020$ & $2018 / 2019$ & $2019 / 2020$ \\
\hline \multicolumn{7}{|c|}{ Irrigation treatments $(I)$} \\
\hline $100 \% \mathrm{WR}$ & 2.30 & 2.36 & 4.312 & 3.697 & 5.104 & 4.906 \\
\hline $85 \%$ WR & 2.55 & 2.52 & 4.388 & 3.567 & 4.693 & 4.930 \\
\hline $70 \%$ WR & 2.80 & 2.91 & 4.197 & 3.713 & 4.691 & 4.958 \\
\hline L.S.D. (0.05) & $N S$ & $N S$ & $N S$ & $N S$ & $N S$ & $N S$ \\
\hline \multicolumn{7}{|c|}{ Harvesting dates $(H)$} \\
\hline 180 days & 2.66 & 2.44 & 4.309 & 3.820 & 4.670 & 4.840 \\
\hline 195 days & 2.54 & 2.59 & 4.304 & 3.826 & 4.905 & 4.846 \\
\hline 210 days & 2.46 & 2.76 & 4.285 & 3.331 & 4.913 & 5.107 \\
\hline L.S.D.(0.05) & $N S$ & $N S$ & $N S$ & 0.313 & $N S$ & $N S$ \\
\hline \multicolumn{7}{|l|}{ Varieties $(V)$} \\
\hline RAVEL & 3.15 & 3.01 & 4.383 & 3.894 & 4.752 & 5.044 \\
\hline SV1841 & 2.01 & 2.14 & 4.040 & 3.577 & 5.023 & 4.878 \\
\hline SA1686 & 2.49 & 2.65 & 4.474 & 3.577 & 4.713 & 4.871 \\
\hline L.S.D. (0.05) & $N S$ & $N S$ & $N S$ & $N S$ & $N S$ & $N S$ \\
\hline \multicolumn{7}{|l|}{ Interactions } \\
\hline IH & $N S$ & $N S$ & $N S$ & $N S$ & $N S$ & $N S$ \\
\hline IV & $N S$ & $N S$ & $N S$ & $N S$ & $N S$ & $N S$ \\
\hline HV & $N S$ & * & $N S$ & $N S$ & $N S$ & $N S$ \\
\hline IHV & $N S$ & $N S$ & $N S$ & $N S$ & $N S$ & $*$ \\
\hline
\end{tabular}

\subsubsection{Effects of the interactions on Alpha amino - N\%, Sodium \%and Potassium (K) \%.}

Moreover, Tables 2 and 3 view the interaction effects between the different combinations for the three studied factors. It could be noted that the effects of the all possible interaction between the studied on impurities percentages $(\alpha-$ amino $\mathrm{N} \%$, $\mathrm{Na} \%$ and $\mathrm{K} \%$ ) were insignificant in the two seasons, except the interaction between harvesting ages and sugar beet varieties on $\alpha$ - amino $\mathrm{N}$ percentages recorded the best value (2.329) by harvesting age 180 days with SV1841 variety in second season only. Tested sugar beet varieties did not behave the same at the different harvesting age, $\alpha-$ amino $\mathrm{N} \%$ was significantly increased by harvesting age 180 days with SV1841 variety but this was not the case with the other two 
varieties. and the interaction between irrigation treatments, harvesting age and sugar beet varieties on $\mathrm{K} \%$ in the second season only was significantly increased, with a recorded value at $6.147 \%$ by $70 \%$ of WR, harvesting age 210 days and RAVEL variety the highest . insignificantly affected in both seasons..$^{33,30,18}$

Table 2. Alpha amino - $\mathrm{N}$ percentages as affected by the interaction between harvesting dates and varieties in two consecutive seasons of 2018/19 and 2019/20.

\begin{tabular}{|c|c|c|c|}
\hline \multirow{2}{*}{ Harvesting dates } & \multirow{2}{*}{ Variety } & \multicolumn{2}{|c|}{ Alpha amino $-\mathrm{N} \%$} \\
\hline & & $2018 / 19$ & $2019 / 20$ \\
\hline \multirow{3}{*}{180 days } & RAVEL & 2.008 & 2.248 \\
\hline & SV1841 & 2.266 & 2.329 \\
\hline & SA1686 & 2.109 & 2.045 \\
\hline \multirow{3}{*}{195 days } & RAVEL & 2.031 & 2.289 \\
\hline & SV1841 & 2.161 & 2.322 \\
\hline & SA1686 & 1.690 & 1.792 \\
\hline \multirow{3}{*}{210 days } & RAVEL & 1.811 & 1.915 \\
\hline & SV1841 & 2.376 & 1.990 \\
\hline & SA1686 & 1.959 & 2.319 \\
\hline L.S.D. 0.05 & & 0.65 & 0.44 \\
\hline
\end{tabular}

Table 3. Potassium $(\mathrm{K})$ percentages as affected by the interaction between irrigation water regimes, harvesting dates and varieties for two growing seasons of 2018/2019 and 2019/2020.

\begin{tabular}{|c|c|c|c|c|c|c|c|}
\hline \multirow[b]{2}{*}{$\begin{array}{l}\text { Irrigation } \\
\text { treatments }\end{array}$} & \multirow[b]{2}{*}{ Harvesting dates } & \multicolumn{2}{|c|}{ 2018/19 } & \multicolumn{4}{|c|}{$2019 / 20$} \\
\hline & & RAVEL & SV1841 & SA1686 & RAVEL & SV1841 & SA1686 \\
\hline \multirow[t]{3}{*}{$100 \%$ WR } & 180 days & 4.790 & 5.250 & 4.370 & 4.943 & 4.813 & 4.643 \\
\hline & 195 days & 4.883 & 5.483 & 5.273 & 5.157 & 5.313 & 4.433 \\
\hline & 210 days & 4.840 & 5.367 & 5.683 & 4.543 & 5.160 & 5.147 \\
\hline \multirow[t]{3}{*}{$85 \%$ WR } & 180 days & 4.793 & 5.127 & 4.463 & 5.180 & 4.210 & 5.257 \\
\hline & 195 days & 4.007 & 4.840 & 4.703 & 5.180 & 4.377 & 4.670 \\
\hline & 210 days & 4.843 & 4.890 & 4.573 & 5.013 & 6.017 & 4.463 \\
\hline \multirow[t]{3}{*}{$70 \%$ WR } & 180 days & 4.900 & 4.800 & 3.540 & 4.080 & 4.720 & 5.717 \\
\hline & 195 days & 5.030 & 4.830 & 5.097 & 5.157 & 4.877 & 4.447 \\
\hline & 210 days & 4.683 & 4.620 & 4.717 & 6.147 & 4.417 & 5.060 \\
\hline L.S.D. (0.05) & & \multicolumn{2}{|c|}{1.41} & \multicolumn{4}{|c|}{1.30} \\
\hline
\end{tabular}

\subsubsection{Effect of irrigation water regimes on sucrose \%, sugar lost to molasses \%and extractable sugar \%}

The results presented in Table 4 clearly indicated that irrigation water regimes on sucrose $\%$ and extractable sugar $\%$ was significant in both growing seasons except the effect of irrigation water regimes on sugar lost to molasses \%was insignificant. Irrigation at $70 \%$ WR and $85 \%$ WR treatments increased sucrose \%by about $10.9 \%$ and $5.2 \%$ in $2018 / 19$ season and by $8.5 \%$ and $4.1 \%$ in the $2019 / 20$ season as compared to $100 \%$ WR treatment. Also, the same treatments increased sugar loss to molasses $\%$ by $2.6 \%$ and $0.04 \%$ in $2018 / 19$ season and $2.4 \%$ and $0.9 \%$ in $2019 / 20$ season as compared by $70 \%$ WR treatment, respectively. Similarly, extractable sugar $\%$ of $85 \%$ WR and $70 \%$ WR irrigation treatments increased by $1.4 \%$ and $0.9 \%$ in $2018 / 19$ season and by $1.1 \%$ and $0.7 \%$ in the $2019 / 20$ season as compared by $100 \%$ WR, respectively. ${ }^{34,35,28}$

\subsubsection{Effect of irrigation water regimes on sucrose \%, sugar lost to molasses \%and extractable sugar \%}

The result of harvesting dates for sucrose $\%$ and extractable sugar $\%$ are presented in Table 4 was significant but sugar lost to molasses \% was not significant. The results clearly indicated that the longest harvesting date gradually creased sucrose $\%$ and extractable sugar $\%$ in both growing seasons. However, the highest sucrose percentage and extractable sugar $\%$ (18.68 and 18.87\%) and (16.92 and 17.27\%) followed by harvesting date of 195 days (18.32 and 18.59\%) and (16.59 and $16.96 \%$ ) while the lowest mean of sucrose percentage and extractable sugar $\%$ by harvesting date of 180 days in the first and second seasons. The highest sugar lost to molasses \% was obtained from the harvesting date of 210 days in the first season and harvesting date of 180 in the second season. ${ }^{36}$

\subsubsection{Effect of sugar beet varieties on sucrose \%, sugar lost to molasses \%and extractable sugar \%.}

Table 4 shows that the results of sugar beet types for sucrose $\%$ and extractable sugar $\%$ were significant, while sugar lost to molasses \% was not. However, in the first and second seasons, the RAVEL variety (20.97 and 20.57 \%) and (19.28 and $17.27 \%)$ had the highest sucrose percentage and extractable sugar \%, followed by SA1686 (17.97 and $18.38 \%)$ and (16.27 and $16.78 \%$ ), and SV1841 had the lowest sucrose percentage and extractable sugar \%. In both seasons, the SA1686 cultivar had the lowest mean percentage of sugar lost to molasses. ${ }^{37,22,38}$ 
Table 4. Means of sucrose $\%$, sugar lost to molasses \% \%and extractable sugar $\%$ of sugar beet crop as effected by irrigation water regimes, harvesting dates and varieties for two growing seasons of 2018/2019 and 2019/2020

\begin{tabular}{|c|c|c|c|c|c|c|}
\hline \multirow{2}{*}{ Treatments } & \multicolumn{2}{|c|}{ Sucrose \% } & \multicolumn{2}{|c|}{ Sugar lost to molasses \% } & \multicolumn{2}{|c|}{ Extractable sugar \% } \\
\hline & $2018 / 2019$ & $2019 / 2020$ & $2018 / 2019$ & $2019 / 2020$ & $2018 / 2019$ & $2019 / 2020$ \\
\hline \multicolumn{7}{|c|}{ Irrigation treatments (I) } \\
\hline $100 \% \mathrm{WR}$ & 17.40 & 17.81 & 2.328 & 2.268 & 15.62 & 16.14 \\
\hline $85 \%$ WR & 18.31 & 18.55 & 2.269 & 2.233 & 16.60 & 16.91 \\
\hline $70 \%$ WR & 19.30 & 19.34 & 2.268 & 2.213 & 17.60 & 17.75 \\
\hline L.S.D. (0.05) & 0.05 & 0.08 & $N S$ & $N S$ & 0.11 & 0.11 \\
\hline \multicolumn{7}{|c|}{ Harvesting dates $(H)$} \\
\hline 180 days & 18.02 & 18.25 & 2.288 & 2.266 & 16.31 & 16.58 \\
\hline 195 days & 18.32 & 18.59 & 2.279 & 2.248 & 16.59 & 16.96 \\
\hline 210 days & 18.68 & 18.87 & 2.299 & 2.199 & 16.92 & 17.27 \\
\hline L.S.D.(0.05) & 0.03 & 0.03 & $N S$ & $N S$ & 0.13 & 0.13 \\
\hline \multicolumn{7}{|l|}{ Varieties $(V)$} \\
\hline RAVEL & 20.97 & 20.57 & 2.266 & 2.289 & 19.28 & 18.88 \\
\hline SV1841 & 16.07 & 16.77 & 2.334 & 2.227 & 14.28 & 15.14 \\
\hline SA1686 & 17.97 & 18.35 & 2.266 & 2.197 & 16.27 & 16.78 \\
\hline L.S.D. (0.05) & 0.03 & 0.05 & 0.12 & 0.10 & 0.13 & 0.10 \\
\hline \multicolumn{7}{|l|}{ Interactions } \\
\hline $\mathrm{IH}$ & $N S$ & $N S$ & $N S$ & $N S$ & $N S$ & $N S$ \\
\hline IV & $*$ & $*$ & $N S$ & $N S$ & * & $*$ \\
\hline HV & $*$ & $*$ & $N S$ & $N S$ & $*$ & $*$ \\
\hline IHV & $*$ & $*$ & $N S$ & $N S$ & $N S$ & $*$ \\
\hline
\end{tabular}

* = significant at F.05 and N.S = not significant

\subsubsection{Effects of the interactions on sucrose \%, sugar lost to molasses \%and extractable sugar \%}

All levels of the interaction's effects presented in Table 4 indicated that only irrigation (I) $\mathrm{x}$ harvesting date $(\mathrm{H})$ showed no significant effects on sucrose $\%$ and extractable sugar $\%$ in the growing season and indicated that irrigation treatments (I) $\mathrm{x}$ harvesting date $(\mathrm{H}) \mathrm{x}$ Varieties $(\mathrm{V})$ showed no significant effects on sucrose $\%$ during the in first season. However, there was no significant effect of the interaction at all levels for sugar loss to molasses $\%$. The results of the effect of the interaction between irrigation treatments and varieties presented in Table 5 indicates that the highest significant sucrose \% and extractable sugar \%was obtained from $70 \%$ WR (22.26and $20.73 \%$ in the first season and 21.72 and $20.06 \%$ in the second season) with RAVEL variety. In addition, the interaction between harvesting date $(\mathrm{H}) \mathrm{x}$ Varieties $(\mathrm{V})$ effects on sucrose $\%$ and extractable sugar $\%$ in the growing season presented in Table (6)indicates that harvesting age $(21.54$ and $21.00 \%$ in the first season and 19.80 and $19.45 \%$ in the second season) with the RAVEL variety produced the highest significant sucrose $\%$ and extractable sugar $\%$.but regarding interaction between irrigation treatments $(\mathrm{I}) \times$ harvesting date $(\mathrm{H}) \times$ Varieties $(\mathrm{V})$ presented in Tables 7 and 8 effects on sucrose $\%$ was significantly in the both season was recorded value at 22.98 and $22.45 \%$ by $70 \%$ of WR, harvesting age 210 days and RAVEL variety the highest and extractable sugar \% in the second season Values of 21.31 and 20.74 percent by $70 \%$ of WR, harvesting age 210 days, and RAVEL variety the highest were recorded.

Table 5. Sucrose $\%$ and extractable sugar $\%$ as affected by the interaction between irrigation treatments and varieties in two consecutive seasons of 2018/19 and 2019/20

\begin{tabular}{|c|c|c|c|c|c|}
\hline \multirow{2}{*}{ irrigation treatments } & \multirow{2}{*}{ Variety } & \multicolumn{2}{|c|}{ Sucrose \% } & \multicolumn{2}{|c|}{ Extractable sugar \% } \\
\hline & & $2018 / 19$ & $2019 / 20$ & $2018 / 19$ & $2019 / 20$ \\
\hline \multirow{3}{*}{$100 \% \mathrm{WR}$} & RAVEL & 19.57 & 19.62 & 17.80 & 17.99 \\
\hline & SV1841 & 15.58 & 15.94 & 13.33 & 14.20 \\
\hline & SA1686 & 17.42 & 17.86 & 15.73 & 16.23 \\
\hline \multirow{3}{*}{$85 \% \mathrm{WR}$} & RAVEL & 20.93 & 20.38 & 19.30 & 18.60 \\
\hline & SV1841 & 16.17 & 16.95 & 14.37 & 15.44 \\
\hline & SA1686 & 17.83 & 18.31 & 16.13 & 16.70 \\
\hline \multirow{3}{*}{$70 \% \mathrm{WR}$} & RAVEL & 22.26 & 21.72 & 20.73 & 20.06 \\
\hline & SV1841 & 16.82 & 17.42 & 15.13 & 15.80 \\
\hline & SA1686 & 18.65 & 18.95 & 16.93 & 17.40 \\
\hline L.S.D.0.05 & & 0.06 & 0.09 & 0.23 & 0.18 \\
\hline
\end{tabular}

Table 6. Sucrose $\%$ and extractable sugar $\%$ as affected by the interaction between Harvesting dates and varieties in first season

\begin{tabular}{|c|c|c|c|c|c|}
\hline \multirow{2}{*}{ Harvesting dates } & \multirow{2}{*}{ Variety } & \multicolumn{2}{|c|}{ Sucrose $\%$} & \multicolumn{2}{|c|}{ Extractable sugar \% } \\
\hline & & $2018 / 19$ & $2019 / 20$ & $2018 / 19$ & $2019 / 20$ \\
\hline \multirow{3}{*}{180 days } & RAVEL & 20.46 & 20.12 & 18.80 & 18.41 \\
\hline & SV1841 & 15.78 & 16.44 & 13.97 & 14.79 \\
\hline & SA1686 & 17.81 & 18.18 & 16.17 & 16.55 \\
\hline \multirow{3}{*}{195 days } & RAVEL & 20.92 & 20.60 & 19.23 & 18.79 \\
\hline & SV1841 & 16.06 & 16.83 & 14.27 & 15.21 \\
\hline & SA1686 & 17.97 & 18.33 & 16.27 & 16.87 \\
\hline \multirow{3}{*}{210 days } & RAVEL & 21.54 & 21.00 & 19.80 & 19.45 \\
\hline & SV1841 & 16.35 & 17.05 & 14.60 & 15.44 \\
\hline & SA1686 & 18.13 & 18.56 & 16.37 & 16.91 \\
\hline L.S.D.0.05 & & 0.06 & 0.09 & 0.23 & 0.18 \\
\hline
\end{tabular}


Table 7. Sucrose \%percentages as affected by the interaction between irrigation water regimes, harvesting dates and varieties for two growing seasons of $2018 / 2019$ and $2019 / 2020$

\begin{tabular}{|c|c|c|c|c|c|c|c|}
\hline \multirow[b]{2}{*}{$\begin{array}{l}\text { Irrigation } \\
\text { treatments }\end{array}$} & \multirow[b]{2}{*}{ Harvesting dates } & \multicolumn{2}{|c|}{$2018 / 19$} & \multicolumn{4}{|c|}{$2019 / 20$} \\
\hline & & RAVEL & SV1841 & SA1686 & RAVEL & SV1841 & SA1686 \\
\hline \multirow[t]{3}{*}{$100 \% \mathrm{WR}$} & 180 days & 19.17 & 14.76 & 17.33 & 19.25 & 15.40 & 17.70 \\
\hline & 195 days & 19.41 & 15.27 & 17.43 & 19.73 & 16.00 & 17.88 \\
\hline & 210 days & 20.13 & 15.58 & 17.51 & 19.88 & 16.43 & 18.00 \\
\hline \multirow[t]{3}{*}{$85 \% \mathrm{WR}$} & 180 days & 20.43 & 15.95 & 17.60 & 20.01 & 16.65 & 18.08 \\
\hline & 195 days & 20.83 & 16.14 & 17.85 & 20.46 & 17.04 & 18.31 \\
\hline & 210 days & 21.52 & 16.42 & 18.05 & 20.66 & 17.16 & 18.55 \\
\hline \multirow[t]{3}{*}{$70 \% \mathrm{WR}$} & 180 days & 21.77 & 16.63 & 18.50 & 21.11 & 17.26 & 18.75 \\
\hline & 195 days & 22.52 & 16.78 & 18.62 & 21.60 & 17.46 & 18.79 \\
\hline & 210 days & 22.98 & 17.06 & 18.84 & 22.45 & 17.55 & 19.13 \\
\hline L.S.D. (0.05) & & \multicolumn{2}{|c|}{0.11} & \multicolumn{4}{|c|}{0.16} \\
\hline
\end{tabular}

Table 8. Extractable sugar percentages as affected by the interaction between irrigation water regimes, harvesting dates and varieties for two growing seasons of 2018/2019 and 2019/2020

\begin{tabular}{|c|c|c|c|c|c|c|c|}
\hline \multirow[b]{2}{*}{$\begin{array}{l}\text { Irrigation } \\
\text { treatments }\end{array}$} & \multirow[b]{2}{*}{ Harvesting dates } & \multicolumn{2}{|c|}{$2018 / 19$} & \multicolumn{4}{|c|}{$2019 / 20$} \\
\hline & & RAVEL & SV1841 & SA1686 & RAVEL & SV1841 & SA1686 \\
\hline \multirow[t]{3}{*}{$100 \% \mathrm{WR}$} & 180 days & 17.40 & 12.90 & 15.70 & 17.53 & 13.66 & 16.12 \\
\hline & 195 days & 17.60 & 13.40 & 15.80 & 17.96 & 14.20 & 16.34 \\
\hline & 210 days & 18.40 & 13.70 & 15.70 & 18.48 & 14.74 & 16.22 \\
\hline \multirow[t]{3}{*}{$85 \% \mathrm{WR}$} & 180 days & 18.90 & 14.00 & 15.90 & 18.18 & 15.09 & 16.30 \\
\hline & 195 days & 19.30 & 14.40 & 16.30 & 18.49 & 15.67 & 16.84 \\
\hline & 210 days & 19.70 & 14.70 & 16.20 & 19.14 & 15.55 & 16.97 \\
\hline \multirow[t]{3}{*}{$70 \% \mathrm{WR}$} & 180 days & 20.10 & 15.00 & 16.90 & 19.51 & 15.61 & 17.22 \\
\hline & 195 days & 20.80 & 15.00 & 16.70 & 19.93 & 15.75 & 17.43 \\
\hline & 210 days & 21.30 & 15.40 & 17.20 & 20.74 & 16.03 & 17.54 \\
\hline L.S.D. (0.05) & & \multicolumn{2}{|c|}{0.40} & \multicolumn{4}{|c|}{0.32} \\
\hline
\end{tabular}

\subsubsection{Effect of irrigation water regimes on QZ\%, Purity \%and extractability sugar\%}

Data presented in Table 9 show the significant effect of irrigation water on QZ \%, extraction sugar \% and sugar lost to molasses \% in the two seasons. Irrigation at 70\% WR treatments increased QZ \% by about $3.8 \%$ and $2.4 \%$ in $2018 / 19$ season and by $2.0 \%$ and $1.3 \%$ in the $2019 / 20$ season as compared to $100 \%$ WR treatment, respectively. Similarly, Purity $\%$ of $70 \%$ WR irrigation treatments increased by $1.4 \%$ and $0.8 \%$ in $2018 / 19$ season and by $0.9 \%$ and $0.6 \%$ in the $2019 / 20$ season as compared to $100 \% \mathrm{WR}$. Also, the same treatments increased extractability sugar $\% .1 .4$ and $0.9 \%$ in $2018 / 19$ season and $1.1 \%$ and $0.7 \%$ in $2019 / 20$ season compared to $100 \%$ WR treatment, respectively. ${ }^{28}$

\subsubsection{Effect of harvesting dates QZ\%, Purity \%and extractability sugar\%.}

Delaying harvest date resulted in Table 9 a no significant increase in Purity \%and extractability sugar\% except the QZ \% was significantly in the second season only, the highest QZ \% was from harvest 210 days $(80.43$ and $81.89 \%)$ in both seasons. 21,40

\subsubsection{Effect of sugar beet varieties on QZ\%, Purity \%and extractability sugar\%}

Table 9. Means of QZ \%, Purity \% and extractability sugar\% of sugar beet crop as effected by irrigation water regimes, harvesting dates and varieties for two growing seasons of 2018/2019 and 2019/2020

\begin{tabular}{|c|c|c|c|c|c|c|}
\hline \multirow{2}{*}{ Treatments } & \multicolumn{2}{|c|}{$\mathrm{QZ} \%$} & \multicolumn{2}{|c|}{ Purity \% } & \multicolumn{2}{|c|}{ Extractability sugar\% } \\
\hline & $2018 / 2019$ & $2019 / 2020$ & $2018 / 2019$ & $2019 / 2020$ & $2018 / 2019$ & $2019 / 2020$ \\
\hline \multicolumn{7}{|c|}{ Irrigation treatments (I) } \\
\hline $100 \% \mathrm{WR}$ & 78.55 & 80.38 & 89.80 & 90.57 & 89.88 & 90.54 \\
\hline $85 \%$ WR & 80.47 & 81.46 & 90.58 & 91.14 & 90.70 & 91.19 \\
\hline $70 \%$ WR & 81.56 & 82.05 & 91.09 & 91.45 & 91.19 & 91.61 \\
\hline L.S.D. (0.05) & 1.58 & 1.03 & 0.43 & 0.37 & 0.60 & 0.52 \\
\hline \multicolumn{7}{|c|}{ Harvesting dates $(H)$} \\
\hline 180 days & 80.10 & 80.84 & 90.39 & 90.79 & 90.43 & 90.81 \\
\hline 195 days & 80.06 & 81.17 & 90.47 & 91.03 & 90.64 & 91.10 \\
\hline 210 days & 80.43 & 81.88 & 90.61 & 91.33 & 90.69 & 91.44 \\
\hline L.S.D. (0.05) & $N S$ & 0.84 & $N S$ & $N S$ & $N S$ & $N S$ \\
\hline \multicolumn{7}{|l|}{ Varieties $(V)$} \\
\hline RAVEL & 82.83 & 80.84 & 91.77 & 91.65 & 91.99 & 91.77 \\
\hline SV1841 & 77.58 & 81.17 & 89.21 & 90.31 & 89.09 & 90.26 \\
\hline SA1686 & 80.17 & 81.88 & 90.49 & 91.19 & 90.69 & 91.30 \\
\hline L.S.D. (0.05) & 1.32 & 1.19 & 0.66 & 0.52 & 0.77 & 0.57 \\
\hline \multicolumn{7}{|l|}{ Interactions } \\
\hline $\mathrm{IH}$ & $N S$ & $N S$ & $N S$ & $N S$ & $N S$ & $*$ \\
\hline IV & $N S$ & $N S$ & $N S$ & $*$ & $N S$ & $N S$ \\
\hline $\mathrm{HV}$ & $*$ & $N S$ & $N S$ & $N S$ & $N S$ & $N S$ \\
\hline IHV & $N S$ & $N S$ & $N S$ & $N S$ & $N S$ & $N S$ \\
\hline
\end{tabular}

* = significant at $\mathrm{F} .05$ and $\mathrm{N} . \mathrm{S}=$ not significant. 
The results in Table 9 clearly showed the best results in QZ \%, Purity \%and extractability sugar\% was significantly in the two seasons obtained from RAVEL variety $(82.48,91.77$ and $91.99 \%)$ in the first season and $(82.66,91.65$ and $91.77 \%)$ in the second season followed by SA1686 variety $(80.17,90.49$ and $90.69 \%)$ in the first season and $(81.57,91.19$ and $91.30 \%)$ in the second season, and SV1841(77.59, 89.21 and 89.09\%)in the first season and (79.69, 90.31and 90.26 \%) in the second season. $41,42,43,25$

\subsubsection{Effects of the interactions on QZ \%, Purity \%and extractability sugar\%}

Regarding the interaction effects between the three studied factors on QZ \%, Purity \%and extractability sugar\%, it is clear that there are insignificant effect by all possible interaction in the two seasons except interaction between harvesting date $(\mathrm{H}) \times$ Varieties (V) presented in Table 10 Showed significantly effects on QZ \% during the in first season indicates that harvesting age195days (83.27) with the RAVEL variety produced the highest significant QZ \%. But regarding the effect of the interaction between irrigation treatments and varieties presented in Table 11 indicates that the highest significant Purity \%and in extractability sugar \% the second season only was obtained from $70 \%$ WR ( 92.9 and 92.35 in the second season) with RAVEL variety, respectively.

Table 10. Means of QZ \%as affected by the interaction between irrigation and varieties in two consecutive seasons of $2018 / 19$ and $2019 / 20$

\begin{tabular}{|c|c|c|c|}
\hline \multirow{2}{*}{ Harvesting dates } & \multirow{2}{*}{ Variety } & \multicolumn{2}{|c|}{ QZ \% } \\
\hline & & $2018 / 19$ & $2019 / 20$ \\
\hline \multirow{3}{*}{180 days } & RAVEL & 82.66 & 82.16 \\
\hline & SV1841 & 76.26 & 79.43 \\
\hline & SA1686 & 81.36 & 80.93 \\
\hline \multirow{3}{*}{195 days } & RAVEL & 83.27 & 81.66 \\
\hline & SV1841 & 77.13 & 79.96 \\
\hline & SA1686 & 79.77 & 81.90 \\
\hline \multirow{3}{*}{210 days } & RAVEL & 82.56 & 84.13 \\
\hline & SV1841 & 79.36 & 79.66 \\
\hline & SA1686 & 79.36 & 81.86 \\
\hline L.S.D. 0.05 & & 2.29 & 2.06 \\
\hline
\end{tabular}

Table 11. Means of Purity \%and extractability sugar\% as affected by the interaction between irrigation and varieties in two consecutive seasons of 2018/19 and 2019/20

\begin{tabular}{|c|c|c|c|c|c|}
\hline \multirow{2}{*}{ irrigation treatments } & \multirow{2}{*}{ Variety } & \multicolumn{2}{|c|}{ Purity \% } & \multicolumn{2}{|c|}{ Extractability sugar\% } \\
\hline & & $2018 / 19$ & $2019 / 20$ & $2018 / 19$ & $2019 / 20$ \\
\hline \multirow{3}{*}{$100 \% \mathrm{WR}$} & RAVEL & 91.00 & 91.63 & 91.23 & 91.68 \\
\hline & SV1841 & 88.17 & 89.27 & 87.90 & 89.05 \\
\hline & SA1686 & 90.23 & 90.81 & 90.50 & 90.88 \\
\hline \multirow{3}{*}{$85 \% \mathrm{WR}$} & RAVEL & 92.03 & 91.24 & 92.30 & 91.28 \\
\hline & SV1841 & 89.33 & 90.94 & 89.20 & 91.08 \\
\hline & SA1686 & 90.37 & 91.24 & 90.60 & 91.22 \\
\hline \multirow{3}{*}{$70 \% \mathrm{WR}$} & RAVEL & 92.27 & 92.09 & 92.43 & 92.35 \\
\hline & SV1841 & 90.13 & 90.73 & 90.17 & 90.66 \\
\hline & SA1686 & 90.87 & 91.53 & 90.97 & 91.82 \\
\hline L.S.D.0.05 & & 1.14 & 0.91 & 1.34 & 0.99 \\
\hline
\end{tabular}

\section{Conclusion}

Results clarified that cultivating either RAVEL or SA1686 varieties with 70\% of water requirement and for 210 growing days under Upper Egypt conditions optimize chemical composition of roots, sucrose present and extractable sugar present.

\section{Experimental}

\subsection{Materials and methods}

A field experiment was carried out at Shandaweel Agricultural Research Station at Sohage, Egypt (latitude of $26^{\circ} 26^{\prime} \mathrm{N}$, longitude of $31^{\circ} 68^{\prime} \mathrm{E}$ and altitude of $70 \mathrm{~m}$ ) in two consecutive seasons of 2018/2019, 2019/2020 to study the effects of three irrigation water regimes and three harvest dates on biomass, roots and sugar yield as well as water use efficiency of three sugar beet varieties grown under upper Egypt conditions. The design of the experiment was split - split block with three replicates. The plot area was $10.5 \mathrm{~m}^{2}(3 \times 3.5 \mathrm{~m})$. The main blocks were subjected to irrigation water regimes where $\mathrm{I}_{1}, \mathrm{I}_{2}$, and $\mathrm{I}_{3}$ represented $100 \%$, as full irrigation requirement treatment and $85 \%$ and $70 \%$ of crop water requirement as deficit irrigation treatments. The sub plots were assigned to the three harvesting dates; $\mathrm{H}_{1}=180, \mathrm{H}_{2}=195$ and $\mathrm{H}_{3}=210$ days from sowing. The sub sub plots comprised three sugar beet varieties namely: $\mathrm{V}_{1}=\mathrm{RAVEL}$ (mono variety), $\mathrm{V}_{2}=$ 
SV1841 (mono variety) and $V_{3}=$ SA1686 (multi-germ). Sugar beet seeds of the three varieties were sown on 8 and 7 November in the 1st and 2nd seasons, respectively. From 3 to 4 seeds were used in each hill $20 \mathrm{~cm}$ apart between two consecutive hills. All treatments were fertilized with P-fertilizer in the form of mono-calcium (MCP) phosphate (15.5\% $\left.\mathrm{P}_{2} \mathrm{O}_{5}\right)$ at the rate $67.5 \mathrm{~kg} \mathrm{P}_{2} \mathrm{O}_{5} / \mathrm{ha}$ added to the soil during land preparation. Nitrogen fertilizer was applied in the form of ammonium nitrate $(33.5 \% \mathrm{~N})$ at the rate of $225 \mathrm{~kg} \mathrm{~N} /$ ha divided into two equal doses (before the first and second irrigation). Potassium fertilizer in the form of potassium sulfate $48 \% \mathrm{~K}_{2} \mathrm{O}$ was applied at the rate of $54 \mathrm{~K}_{2} \mathrm{O} /$ ha and added during the second irrigation. The other farming practices required for sugar beet growth were carried out according to the common practices followed at Shandaweel station. Traditional furrow irrigation method for irrigation was used during both growing seasons.

Recorded data:

Plant samples were then sent to the laboratory of quality analyses at laboratory of Abu Kurgas to determine the following quality characteristics:

At each of the studied harvest ages, a random sample of five guarded roots of each plot was taken to determine the following traits:

1. Root impurities in terms of $\alpha$-amino N, Na and K percentages (meq/100 g beet) according to . ${ }^{44}$

2. Sucrose percentage which was estimated in fresh samples of sugar beet root using "Saccharometer" according to the method described by 44

3. Sugars lost to molasses percentage (SLM \%) was calculated as described by ${ }^{45}$ using the following equation: SLM $\%=$ $[0.14(\mathrm{Na}+\mathrm{K})+0.25(\alpha$-amino $\mathrm{N})+0.5]$

4. Extractable sugar percentage $(\mathrm{ES} \%)$ was calculated using the equation of ${ }^{46}$ as follows: ES\% $=[$ sucrose $\%-($ sugar lost to molasses $\%+0.6)]$.

5- (QZ) was calculated as following $\mathrm{QZ}=\mathrm{ZB} / \mathrm{Pol} \times 100$.Impurities percentage \%calculated as the formula $\mathrm{ZB}=\mathrm{Pol}$

- $\{(\mathrm{K}+\mathrm{Na}) \mathrm{x} 0.0343)+($ alpha-amino $\mathrm{N} \times 0.094)+0.29\}$ as described by. ${ }^{47}$

Where: $\mathrm{ZB}=$ corrected sugar content (\% beet)

6. Purity percentage was calculated according to the following equation, described by Devillers (1988): Purity \% $=99.36$

$-[14.27(\mathrm{Na}+\mathrm{K}+\alpha$-amino $\mathrm{N}) /$ sucrose $\%]$.

7. Extractability $=[($ extractable sugar $\% /$ sucrose $\%) \times 100]$.

Table 12. Average values of meteorological data recorded at Shandaweel Agricultural Research Station in 2018/2019 and 2019/2020 growing seasons

\begin{tabular}{|c|c|c|c|c|c|c|c|c|c|c|}
\hline \multirow{3}{*}{ Months } & \multicolumn{5}{|c|}{$2018 / 2019$} & \multicolumn{5}{|c|}{$2019 / 2021$} \\
\hline & \multicolumn{2}{|c|}{ Temperature $\left({ }^{\circ} \mathrm{C}\right)$} & \multirow{2}{*}{ RH (\%) } & \multirow{2}{*}{$\mathrm{WS} \mathrm{m} / \mathrm{sec}$} & \multirow{2}{*}{$\begin{array}{l}\text { SR } \\
(\%)\end{array}$} & \multicolumn{2}{|c|}{ Temperature $\left({ }^{\circ} \mathrm{C}\right)$} & \multirow{2}{*}{ RH (\%) } & \multirow{2}{*}{$\mathrm{WS} \mathrm{m} / \mathrm{sec}$} & \multirow{2}{*}{$\begin{array}{l}\text { SR } \\
(\%)\end{array}$} \\
\hline & Max. & Min. & & & & Max. & Min. & & & \\
\hline Nov. & 26.6 & 13.0 & 54 & 2.3 & 13 & 28.8 & 14.5 & 59 & 2.3 & 17 \\
\hline Dec. & 20.3 & 7.1 & 65 & 2.5 & 15 & 21.7 & 7.9 & 58 & 2.4 & 15 \\
\hline Jan. & 18.8 & 5.0 & 60 & 2.1 & 15 & 18.3 & 4.3 & 58 & 2.5 & 15 \\
\hline Feb. & 21.5 & 7.1 & 48 & 2.6 & 18 & 21.4 & 6.6 & 52 & 2.6 & 19 \\
\hline Mar. & 25.1 & 9.1 & 35 & 2.9 & 23 & 27.2 & 10.6 & 45 & 3.1 & 22 \\
\hline Apr. & 30.1 & 13.8 & 34 & 3.2 & 24 & 30.1 & 14.0 & 37 & 3.4 & 25 \\
\hline May & 38.4 & 20.8 & 30 & 3.0 & 27 & 36.0 & 19.8 & 36 & 3.4 & 27 \\
\hline
\end{tabular}

$\mathrm{WS}=$ wind speed $\mathrm{m} / \mathrm{sec} ; \mathrm{SR}=$ solar radiation, $\mathrm{MJ} / \mathrm{m}^{2} /$ day, $\mathrm{RH}=$ relative humidity in $\% \mathrm{ETo}=$ evapotranspiration, $\mathrm{mm}$

\section{Statistical analysis}

The obtained data were subjected to statistical analysis of variance using MSTAT_C computer program. The means were compered for significant differences using the L.S.D. at $\mathrm{p}=0.05 .^{48}$

This work confirms the importance of scientific research in different fields. ${ }^{49-53}$

\section{References}

1 Abdel-Raheem Sh. A. A., Kamal El-Dean A. M., Hassanien R., El-Sayed M. E. A., and Abd-Ella A. A. (2020) Synthesis and biological activity of 2-((3-Cyano-4,6-distyrylpyridin-2-yl)thio)acetamide and its cyclized form. Alger. j. biosciences, 01 (02) 046-050.

2 Bakhite E. A., Abd-Ella A. A., El-Sayed M. E. A., and Abdel-Raheem Sh. A. A. (2014) Pyridine derivatives as insecticides. Part 1: Synthesis and toxicity of some pyridine derivatives against Cowpea Aphid, Aphis craccivora Koch (Homoptera: Aphididae). J. Agric. Food Chem., 62 (41) 9982-9986.

3 Abdelhamid A. A., Elsaghier A. M. M., Aref S. A., Gad M. A., Ahmed N. A., and Abdel-Raheem Sh. A. A. (2021) Preparation and biological activity evaluation of some benzoylthiourea and benzoylurea compounds. Curr. Chem. Lett., 10 (4) 371-376. 
4 Bakhite E. A., Abd-Ella A. A., El-Sayed M. E. A., and Abdel-Raheem Sh. A. A. (2017) Pyridine derivatives as insecticides. Part 2: Synthesis of some piperidinium and morpholinium cyanopyridinethiolates and their Insecticidal Activity. J. Saud. Chem. Soc., 21 (1) 95-104.

5 Kamal El-Dean A. M., Abd-Ella A. A., Hassanien R., El-Sayed M. E. A., Zaki R. M., and Abdel-Raheem Sh. A. A. (2019) Chemical design and toxicity evaluation of new pyrimidothienotetrahydroisoquinolines as potential insecticidal agents. Toxicol. Rep., 6 (2019) 100-104.

6 Gad M. A., Aref S. A., Abdelhamid A. A., Elwassimy M. M., and Abdel-Raheem Sh. A. A. (2021) Biologically active organic compounds as insect growth regulators (IGRs): introduction, mode of action, and some synthetic methods. Curr. Chem. Lett., 10 (4) 393-412.

7 Kamal El-Dean A. M., Abd-Ella A. A., Hassanien R., El-Sayed M. E. A., and Abdel-Raheem Sh. A. A. (2019) Design, Synthesis, Characterization, and Insecticidal Bioefficacy Screening of Some New Pyridine Derivatives. ACS Omega, 4 (5) 8406-8412.

8 Abdel-Raheem Sh. A. A., Kamal El-Dean A. M., Zaki R. M., Hassanien R., El-Sayed M. E. A., Sayed M., and Abd-Ella A. A. (2021) Synthesis and toxicological studies on distyryl-substituted heterocyclic insecticides. Eur. Chem. Bull., 10 (4) 225-229.

9 Abdel-Raheem Sh. A. A., Kamal El-Dean A. M., Hassanien R., El-Sayed M. E. A., and Abd-Ella A. A. (2021) Synthesis and characterization of some distyryl-derivatives for agricultural uses. Eur. Chem. Bull., 10 (1) 35-38.

10 Tolba M. S., Sayed M., Abdel-Raheem Sh. A. A., Gaber T. A., Kamal El-Dean A. M., and Ahmed M. (2021) Synthesis and spectral characterization of some new thiazolopyrimidine derivatives. Curr. Chem. Lett., 10 (4) 471-478.

11 Al-Taifi E. A., Abdel-Raheem Sh. A. A., and Bakhite E. A. (2016) Some reactions of 3-cyano-4- $(p-$ methoxyphenyl)-5-oxo-5,6,7,8-tetrahydroquinoline-2(1H)-thione; Synthesis of new tetrahydroquinolines and tetrahydrothieno[2,3-b]quinolines. Assiut University Journal of Chemistry (AUJC), 45 (1) 24-32.

12 Abdel-Raheem Sh. A. A., Kamal El-Dean A. M., Hassanien R., El-Sayed M. E. A., Sayed M., and Abd-Ella A. A. (2021) Synthesis and spectral characterization of selective pyridine compounds as bioactive agents. Curr. Chem. Lett., 10 (3) 255-260.

13 Abdel-Raheem Sh. A. A., Kamal El-Dean A. M., Abd ul-Malik M. A., Abd-Ella A. A., Al-Taifi E. A., Hassanien R., El-Sayed M. E. A., Mohamed S. K., Zawam S. A., and Bakhite E. A. (2021) A concise review on some synthetic routes and applications of pyridine scaffold compounds. Curr. Chem. Lett., 10 (4) 337-362.

14 Tolba M. S., Kamal El-Dean A. M., Ahmed M., Hassanien R., Sayed M., Zaki R. M., Mohamed S. K., Zawam S. A., Abdel-Raheem Sh. A. A. (2021) Synthesis, reactions, and applications of pyrimidine derivatives. Curr. Chem. Lett., Accepted Manuscript (DOI: 10.5267/j.ccl.2021.8.002).

15 Abdelhafeez I. A., El-Tohamy S. A., Abd ul-Malik M. A., Abdel-Raheem Sh. A. A., and El-Dars F. M. S. (2021) A review on green remediation techniques for hydrocarbons and heavy metals contaminated soil. Curr. Chem. Lett., Accepted Manuscript (DOI: 10.5267/j.ccl.2021.9.006).

16 Tolba M. S., Abd ul-Malik M. A., Kamal El-Dean A. M., Geies A. A., Radwan Sh. M., Zaki R. M., Sayed M., Mohamed S. K., and Abdel-Raheem Sh. A. A. (2021) An overview on synthesis and reactions of coumarin based compounds. Curr. Chem. Lett., Accepted Manuscript (DOI: 10.5267/j.ccl.2021.9.007).

17 Abdel-Raheem Sh. A. A., Kamal El-Dean A. M., Abd ul-Malik M. A., Hassanien R., El-Sayed M. E. A., AbdElla A. A., Zawam S. A., and Tolba M. S. (2021) Synthesis of new distyrylpyridine analogues bearing amide substructure as effective insecticidal agents. Curr. Chem. Lett., Accepted Manuscript (DOI: 10.5267/j.ccl.2021.10.001).

18 Thalooth A. T., Tawfik M. M., Badre E. A., and Mohamed M. H. (2019) Yield and quality response of some sugar beet (Beta vulgaris L.) varieties to humic acid and yeast application in newly reclaimed soil. Middle East J. Agric. Res., 8 (1) 56-65.

19 Winter SR. (1980) Suitability of Sugar Beet for limited irrigation in a semi-arid climate. J. Agron., 72 118-123.

20 Hemayati S. S., Shirzadi M. H., Aghaeezadeh M., Taleghani D. F., Javaheri M. A., and Aliasghari A. (2012) Evaluation of sowing and harvesting date effects on yield and quality of five sugar beet cultivars in Jiroft region (autumn planting). J. Sugar Beet Res., 28 (1) 42-25.

21 Abo El-Ghait R. A. (2013) Response of some sugar beet varieties to time of harvest. Egyptian Journal of Applied Sciences (EJAS), 28 (3) 204-215.

22 Hanan M. Y., and Yasin M. A. T. (2013) Response of some sugar Beet varieties to harvesting dates and foliar application of boron and zinc in sandy Soil. Egypt. J. Agron., 35 (2) 227- 252.

23 Al-Labody A. H. S., Nafi A. I., and Aly E. F. (2012) Response of some sugar beet varieties to nitrogen sources under the newly reclaimed soil. Egyptian Journal of Applied Sciences (EJAS), 27 (4) 152-160.

24 Kaloi, G. M., HMari A., Zubair M. ., Panhwar R. ., Bughio N. N., Junejo S., Unar G. S., and Bhutt M. A. (2014) Performance of exotic sugar beet varieties under agro-climatic conditions of lower Sindh. J. Anim. Plant Sci., 28 (1) $13-21$.

25 Mekdad A. A. A., and M. M. Rady (2016) Response of Beta vulgaris L. to nitrogen and micronutrients in dry environment. J. Plant Soil Environ., 62 (1) 23-29.

26 Winter S R. (1990) Sugar beet response to nitrogen as affected by seasonal irrigation. J. Agron., 82 984-988. 
27 Last P. J., Draycott A. P., Messem A. B., and Webb D. J. (2009) Effects of nitrogen fertilizer and irrigation on sugar beet at Broom's Barn 1973-8. J. Agric. Sci., 101 185-205

28 Abou-Elwafa S. F., Amin A. E. E. A., and Eujay I. (2020) Genetic diversity of sugar beet under heat stress and deficit irrigation. J. Agron., 112 (5) 3579-3590.

29 Abou-Salama C.N.J., and S.I. El-Syiad A.M. (2000) Studies on some sugar beet cultivars under Middle Egypt conditions. I. Response to planting and harvesting dates. Assiut Journal of Agricultural Sciences (AJAS), 31 (1) 137-159.

30 Al-Sayed H. M., El-Razek U. A. A., Sarhan H. M., and Fateh, H. S. (2012) Effect of harvest dates on yield and quality of sugar beet varieties. Aust. j. basic appl. sci., 6 (9) 525-529.

31 Heidari G., Sohrabi Y., and Esmailpoor B. (2008) Influence of harvesting time on yield and yield components of sugar beet. J. Agri. Soc. Sci., 4 (2) 69-73.

32 Nagib S. R., El-Azez A., and Ali A. M. K. (2018) Evaluation of some New Sugar Beet Varieties as Affected by Different Harvest Ages under Conditions of Minia Governorate. J. Plant Prod. Sci., 9 (12) 1175-1180.

33 Safina S. A., and Abdel Fatah E. M. (2011) Response of three sugar beet varieties to compost, mineral nitrogen fertilizer and their combinations under sandy soil conditions IIYield and quality. Bull. Fac. Agric., Cairo Univ., 62 (4) 447-456.

34 Esmaeili M.A. (2011) Evaluation of the effects of water stress and different levels of nitrogen on sugar beet (Beta vulgaris). Inter. J. Biol., 3 (2) 89-93.

35 Masri M. I., Ramadan B. S. B., El-Shafai, A .M. A., and El-Kady M. S. (2015) Effect of water stress and fertilization on yield and quality of sugar beet under drip and sprinkler irrigation systems in sandy soil. Int. J. Agric. Sci., 5 (3) 414-425.

36 Aly E. F. A. (2006) Effect of environmental conditions on productivity and quality of some sugar beet varieties. Ph.D. Thesis, Fac. of Agric., Benha Univ., Egypt.

37 Abd El-Aal A. M., Nafie A. I., and Abdel Aziz Ranya M. (2010) Response of some sugar beet genotypes to nitrogen fertilization under newly reclaimed land conditions. Egyptian Journal of Applied Sciences (EJAS), 25 (6B) 194-208.

38 Enan S. A. A. M., Aly E. F. A., and Badr A. I. (2016) Effect of humic acid and potassium on yield and quality of some sugar beet varieties in sandy soil. J. Plant Prod. Mansoura Univ., 7 (2) 289 -297.

39 Awad N. M. M., Abdel-daiem A., and Moustafa S. M. I. (2014) Evaluation of siand sugar beet varieties under three harvest dates. Minufiya J. Agric.Res., 39 (1) 121-130.

40 Klara P., Jaromir C., Josef P., and Jaroslav U. (2017) Influence of sowing and harvest dates on production of two different cultivars of sugar beet. Plant Soil Environ., 63 (2) 76-81.

41 Gobarah M. E., and Mekki B. B. (2005) Influence of boron application on yield and juice quality of some sugar beet cultivars grown under saline soil conditions. Res. J. Appl. Sci., 1 (5) 373-379.

42 Ahmed S., Zubair M ., Iqbal N., Cheema N. M., and Mahmood K. (2012) Evaluation of sugar beet hybrid varieties under ThalKumbi in Pakistan. J. Agric. Biol., 14 (4) 605-608.

43 Hozayn M. (2013) Screening of some exotic sugar beet cultivars grown under newly reclaimed sandy soil for yield and sugar quality traits. J. Appl. Sci. Res., 9 (3) 2213-2222.

44 A. O. A. C. (2005) Association of Official Analytical Chemists. "Official Methods of Analysis", $16^{\text {th }}$ ed. Inter. Washington, D. C. USA.

45 Devillers P. (1988) Prevision du sucre melasse. Scurries francases 129, 190-200. (C. F. The Sugar Beet Crop Book).

46 Dexter S. T., Frakes M. G., and Snyder F. W. (1967) Arapid and practical method of determining extractable white sugar as may be applied to the evaluation of agronomic practices and grower deliveries in the sugar beet industry. J. Am. Soc. Sugar Beet Tech., 14 433-454.

47 Carruthers A., Oldfield J. F.T., and Teague H. J. (1962) Assessment of beet quality.InThe15 ${ }^{\text {th }}$ Annual Technical Conference. British Sugar Corporation Ltd., p. 28.

48 Steel R. G. D., and Torrie J. H. (1982) Principals and Procedures of Statistics A Biometrical Approach. Mc Graw Hill Book Company, New York. USA.

49 Saber A. F., Sayed M., Tolba M. S., Kamal A. M., Hassanien R., and Ahmed M. (2021) A Facile Method for Preparation and Evaluation of the Antimicrobial Efficiency of Various Heterocycles Containing Thieno[2,3d]Pyrimidine. Synth. Commun, 51 (3) 398-409.

50 Ahmed M., Sayed M., Saber A. F., Hassanien R., Kamal El-Dean A. M., and Tolba M. S. (2020) Synthesis, Characterization, and Antimicrobial Activity of New Thienopyrimidine Derivatives. Polycycl. Aromat. Compd., Accepted Manuscript (DOI: 10.1080/10406638.2020.1852587).

51 Kamal El-Dean A. M., Zaki R. M., Radwan S. M., and Saber A. F. (2017) Synthesis, Reactions and Spectral Characterization of Novel Thienopyrazole Derivatives. Eur. Chem. Bull., 6 (12) 550-553.

52 Zaki R. M., Kamal El-Dean A. M., Radwan S. M., and Saber A. F. (2019) Efficient synthesis, reactions and spectral characterization of novel pyrazolo $\left[4^{\prime}, 3^{\prime}: 4,5\right]$ thieno[3,2-d]pyrimidine derivatives and their related heterocycles. Heterocycl. Commun., 25 (1) 39-46. 
53 Saber A. F., Zaki R. M., Kamal El-Dean A. M., and Radwan S. M. (2020) Synthesis, reactions and spectral characterization of some new biologically active compounds derived from thieno[2,3-c]pyrazole-5carboxamide. J. Heterocyclic Chem., 57 (1) 238-247.

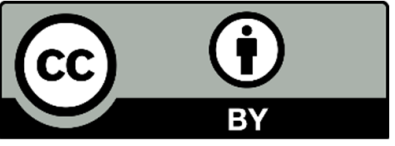

(C) 2022 by the authors; licensee Growing Science, Canada. This is an open access article distributed under the terms and conditions of the Creative Commons Attribution (CC-BY) license (http://creativecommons.org/licenses/by/4.0/). 